\title{
Nanoscale
}

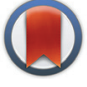

CrossMark $\leftarrow$ click for updates

Cite this: Nanoscale, 2015, 7, 1301

Received 10th September 2014 Accepted 2nd December 2014

DOI: $10.1039 / c 4 n r 05244 g$

www.rsc.org/nanoscale

\section{A high-performance catalyst support for methanol oxidation with graphene and vanadium carbonitride $\uparrow$}

\author{
Taizhong Huang, ${ }^{*}{ }^{\mathrm{a}}, \mathrm{b}$ Shun Mao, ${ }^{\mathrm{b}}$ Guihua Zhou, ${ }^{\mathrm{b}}$ Zhaoliang Zhang, ${ }^{\mathrm{a}}$ Zhenhai Wen, \\ Xingkang Huang, ${ }^{b}$ Suqin $\mathrm{Ci}^{\mathrm{b}}$ and Junhong Chen*b
}

In this study, a graphene-vanadium carbonitride $(G-V(C, N))$ hybrid is reported as a novel support for the Pt catalyst in methanol oxidation. The catalytic activity of the Pt/G-V(C,N) hybrid for methanol oxidation is greatly enhanced compared with that of a commercial $\mathrm{Pt} / \mathrm{C}$ catalyst with carbon black as the catalyst support. The outstanding catalytic activity of the $P t / G-V(C, N)$ catalyst suggests the potential of using graphene-metal carbonitride as the catalyst support in fuel cells.

\section{Introduction}

The direct methanol fuel cell (DMFC), one of the most promising energy sources for portable devices and transportation applications, has attracted great attention in recent years. The appealing features of a DMFC include high efficiency, high energy density, low operating temperature, environmentally benign quality, and the ability to generate power without distributed pollution from by-products of hydrocarbon combustion. However, the poor activity and the high cost of the anode catalysts still block their large-scale applications.

Rare metal-based catalysts, e.g., platinum (Pt)-based catalysts, are the most popular catalysts for methanol oxidation. Recently, Pt-based alloys, i.e., Pt-Au, Pt-Ru, Pt-Rh, Pt-Pd, and Pt-Sn, were studied and they showed improved catalytic activities compared with pure Pt for methanol oxidation in alkaline electrolytes. ${ }^{1-3}$ Traditionally, metallic catalyst particles are usually loaded on a carbon black support due to its low cost,

\footnotetext{
${ }^{a}$ Key Laboratory of Chemical Sensing \& Analysis in Universities of Shandong, School of Chemistry and Chemical Engineering, University of Jinan, Jinan 250022, China. E-mail: chm_huangtz@ujn.edu.cn; Fax: +86531 82765969; Tel: +8653189716103 ${ }^{b}$ Department of Mechanical Engineering, University of Wisconsin-Milwaukee, 3200 North Cramer Street, Milwaukee, WI 53211, USA. E-mail: jhchen@uwm.edu; Fax: +1 414 2296958; Tel: +14142292615

$\dagger$ Electronic supplementary information (ESI) available: DSC results of Pt/G-V(C, N); TEM image of Pt/G-V(C, N); XPS and Raman results of Pt/G-V(C, N); catalytic performance of Pt/graphene in methanol oxidation; electrochemical surface area calculation. See DOI: 10.1039/c4nr05244g

$\$$ These authors contributed equally to this work.
}

large specific surface area, and good electrical conductivity; however, the shortcomings of carbon black are also prominent, such as the absence of an synergistic effect with catalysts and an easily corroded and collapsed structure during longterm operation. The corrosion of carbon black can induce the poisoning of precious metal catalysts by carbon monoxide, while the structure collapse can induce the agglomeration of catalyst particles, leading to degradation in the catalyst catalytic activity. ${ }^{4}$ To overcome the shortcomings of carbon black, various new catalyst supports such as metal oxides, carbides, and nitrides have been proposed due to their anti-corrosion, synergistic effect, lower methanol oxidation onset potential, less formation of formic acid or formaldehyde and so on. ${ }^{5-12}$ Metal oxides, such as $\mathrm{CeO}_{2}, \mathrm{RuO}_{2}, \mathrm{NiO}, \mathrm{Co}_{3} \mathrm{O}_{4}$, and $\mathrm{Mn}_{3} \mathrm{O}_{4}$, can significantly promote the catalytic activity and stability of $\mathrm{Pt} / \mathrm{C}$ or $\mathrm{Pd} / \mathrm{C}$ electro-catalysts for methanol oxidation. ${ }^{13-15}$ Compared with metal oxides, metal nitride- and carbide-supported catalysts show even higher catalytic activity and stability for methanol oxidation. For example, titanium nitride (TiN)supported Pt shows good catalytic performance and high CO tolerance for methanol oxidation in an alkaline medium with exceptional stability, corrosion resistance, good electronic conductivity and adhesion behaviour. ${ }^{16-18}$ A microspheric $\mathrm{W}_{2} \mathrm{C}-$ supported Pt catalyst shows higher catalytic activity for the electrochemical oxidation of methanol compared with a carbon black-supported commercial Pt-Ru/C catalyst. ${ }^{19}$ Molybdenum carbide (MoC) and tungsten carbide (WC) supported Pt-Ru catalysts also display better durability and higher catalytic performance than the $\mathrm{Pt}-\mathrm{Ru} / \mathrm{C}$ catalyst. ${ }^{20}$ Lee's group recently reviewed transitional metal carbide (TMC) and transitional metal nitride (TMN) catalysts towards methanol oxidation. ${ }^{21}$ TMC-based electrocatalysts are believed to be more active as anode catalysts for the oxidation of fuels, whereas TMN-based catalysts are more active as cathode catalysts for oxygen reduction with a high stability. Another review of the electrochemical determination of activation energies for methanol oxidation on $\mathrm{Pt}$ in acidic and alkaline electrolytes drew similar conclusions, ${ }^{22}$ and the carbide and nitride anions play a critical role in catalyzing the methanol oxidation 
through different mechanisms. In addition to the metal nitride and carbide supports, nanocarbon, e.g., a graphenebased catalyst support, has also attracted great attention due to its high surface area and high conductivity. ${ }^{23,24}$

Although various metal carbides and nitrides have been investigated as catalyst supports, using metal carbonitride as a catalyst support for methanol oxidation has scarcely been reported. A heterogeneous catalyst, e.g., metal carbonitride, provides new opportunities for improving the catalytic performance owing to the multi-functionality inherent in the catalytic process. ${ }^{25-27}$ Due to the coexistence of nitrogen and carbon anions, many defects are present in metal carbonitride, which leads to increased active sites and induces synergistic effects with the catalyst.

In this study, a graphene supported vanadium carbonitride $(\mathrm{V}(\mathrm{C}, \mathrm{N}))$ hybrid, termed $(\mathrm{G}-\mathrm{V}(\mathrm{C}, \mathrm{N}))$, was successfully synthesized through in situ reduction of graphene oxide (GO) supported $\mathrm{V}_{2} \mathrm{O}_{3}$ under an ammonia atmosphere. ${ }^{28,29} \mathrm{Pt}$ nanoparticles, a typical catalyst for methanol oxidation, were loaded on the $\mathrm{G}-\mathrm{V}(\mathrm{C}, \mathrm{N})$ for methanol oxidation. The electrochemical tests show that the catalytic activity of $\mathrm{Pt} / \mathrm{G}-\mathrm{V}(\mathrm{C}, \mathrm{N})$ for methanol oxidation is much higher than that of the commercial Pt/C catalyst, which suggests that $\mathrm{G}-\mathrm{V}(\mathrm{C}, \mathrm{N})$ is a promising catalyst support for methanol oxidation in fuel cell systems.

\section{Materials and methods}

\section{Synthesis of Pt/G-V(C, N)}

Graphene oxide-supported $\mathrm{V}_{2} \mathrm{O}_{3}$ was prepared by a hydrothermal method using $\mathrm{VCl}_{3}$ as the precursor. First, $0.2 \mathrm{~g} \mathrm{\textrm {VCl } _ { 3 }}$ (97\%, Aldrich) and $8.0 \mathrm{ml}$ graphene oxide (GO) $\left(10 \mathrm{mg} \mathrm{ml}^{-1}\right.$ in DI water, ACS Materials) were mixed with ultra-sonication for thirty minutes. Then a hydrothermal reaction occurred at $200{ }^{\circ} \mathrm{C}$ for eight hours and the obtained precipitate was washed with a large amount of DI water and vacuum dried at $80{ }^{\circ} \mathrm{C}$ for four hours. The resulting graphene oxide-supported $\mathrm{V}_{2} \mathrm{O}_{3}$ was reduced at $1000{ }^{\circ} \mathrm{C}$ under an ammonia gas flow (0.5 lpm, quarter inch tube) for two hours to produce the $\mathrm{G}-\mathrm{V}$ (C, N) support. Pt, with the content of $10 \mathrm{wt} \%$, was loaded onto $\mathrm{G}-\mathrm{V}(\mathrm{C}, \mathrm{N})$ by the reduction of $\mathrm{H}_{2} \mathrm{PtCl}_{6}$ using ethylene glycol under sonication conditions at $60{ }^{\circ} \mathrm{C}$. The content of Pt (10 wt\%), V (35.3 wt\%), and N (9.1 wt\%) was obtained using inductively coupled plasma atomic emission spectroscopy (ICP-AES) tests. The hybrid was then further annealed at $400{ }^{\circ} \mathrm{C}$ for one hour and the annealing temperature was determined using the differential scanning calorimetry (DSC) result, as shown in ESI† Fig. S1a.

\section{Material characterization}

The morphology of the $\mathrm{Pt} / \mathrm{G}-\mathrm{V}(\mathrm{C}, \mathrm{N})$ sample, the selected area electron diffraction (SAED) pattern, the energy-dispersive X-ray spectroscopy (EDS), and the elemental mapping were obtained using a Hitachi (H 9000 NAR) transmission electron microscope (TEM) and a Hitachi (S-4800) scan electron microscope
(SEM) equipped with an energy-dispersive X-ray spectroscopy analyzer. Samples for SEM tests were loaded on the silicon substrate first before tests. A powder X-ray diffraction (XRD) test was performed on a Scintag XDS 2000 X-ray powder diffractometer with monochromatized $\mathrm{Cu} \mathrm{K} \alpha$ radiation $(\lambda=$ $1.5418 \AA$ ); the data were collected between diffraction angles

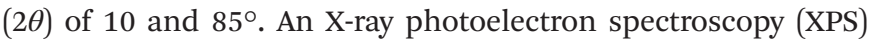
test was conducted using an HP 5950A ESCA spectrometer with an $\mathrm{Mg} \mathrm{K} \alpha$ source. Raman spectroscopy was obtained using a Renishaw Raman system with a $633 \mathrm{~nm}$ laser line from an He-Ne laser.

\section{Electrochemical test}

The electrochemical characterization was carried out in $1 \mathrm{M} \mathrm{KOH}$ at room temperature using a CHI 760E electrochemical workstation (CHI Inc., USA). The three-electrode cell consisted of an $\mathrm{Hg} / \mathrm{Hg}_{2} \mathrm{Cl}_{2}$ electrode as the reference electrode, $\mathrm{Pt}$ as the counter-electrode, and a glassy carbon electrode with catalysts as the working electrode. To prepare the working electrode, $5.0 \mathrm{mg}$ catalyst was mixed with a $50 \mu \mathrm{L}$ Nafion solution (5.0\% Nafion in ethanol) and $450 \mu \mathrm{L}$ DI water. The mixture was sonicated for more than thirty minutes and $5.0 \mu \mathrm{L}$ of the suspension was dropped onto a glassy-carbon electrode with a diameter of $3 \mathrm{~mm}$ and then fully dried. Before electrochemical tests, the working electrode was kept in an Ar-saturated electrolyte by cycling the potential from 0.2 to $-0.8 \mathrm{~V}$ at a sweeping rate of $100 \mathrm{mV} \mathrm{s}^{-1}$ until reproducible results were obtained. Thereafter, the methanol electrolyte was added and cyclic voltammogram tests were carried out for methanol oxidation from 0.2 to $-0.8 \mathrm{~V}$ at sweeping rates of $5,10,20,50$, and $100 \mathrm{mV} \mathrm{s}^{-1}$. The influence of methanol concentration on the catalyst catalytic performance was tested with methanol concentrations ranging from 0.1 to $2.0 \mathrm{M}$. As a reference, the commercial Pt/C catalyst, with $10 \mathrm{wt} \%$ Pt content, was tested using the same procedure. The specific current density in this study was evaluated using the surface area of the electrode $\left(0.07 \mathrm{~cm}^{2}\right)$. However, since the electrochemical surface area (ECSA) is an important factor in electrochemical measurements, the ECSA of the catalyst was also calculated and details of ECSA calculations are provided in the ESI. $\dagger$

\section{Results and discussion}

The catalyst was prepared by depositing Pt on $\mathrm{G}-\mathrm{V}(\mathrm{C}, \mathrm{N})$ by the reduction of platinum chloride acid using the sonication method. To study the structure of the catalysts, the samples were first characterized by XRD spectroscopy. Based on the XRD patterns shown in Fig. 1a, the coexistence of Pt, carbon, and $\mathrm{V}(\mathrm{C}, \mathrm{N})$ was evidenced in the $\mathrm{Pt} / \mathrm{G}-\mathrm{V}(\mathrm{C}, \mathrm{N})$ catalysts. The carbon signal comes from the reduced GO (RGO) that serves as a support and carbon source for $\mathrm{V}(\mathrm{C}, \mathrm{N})$. The XRD peaks of $\mathrm{V}(\mathrm{C}, \mathrm{N})$ and $\mathrm{Pt}$ are indexed to face centered cubic (FCC) anatase $\mathrm{V}(\mathrm{C}, \mathrm{N})$ and $\mathrm{FCC} \mathrm{Pt}$, respectively. The XRD results suggest that the prepared hybrids are composed of Pt, RGO and $\mathrm{V}(\mathrm{C}, \mathrm{N})$ with no detectable impurities. 

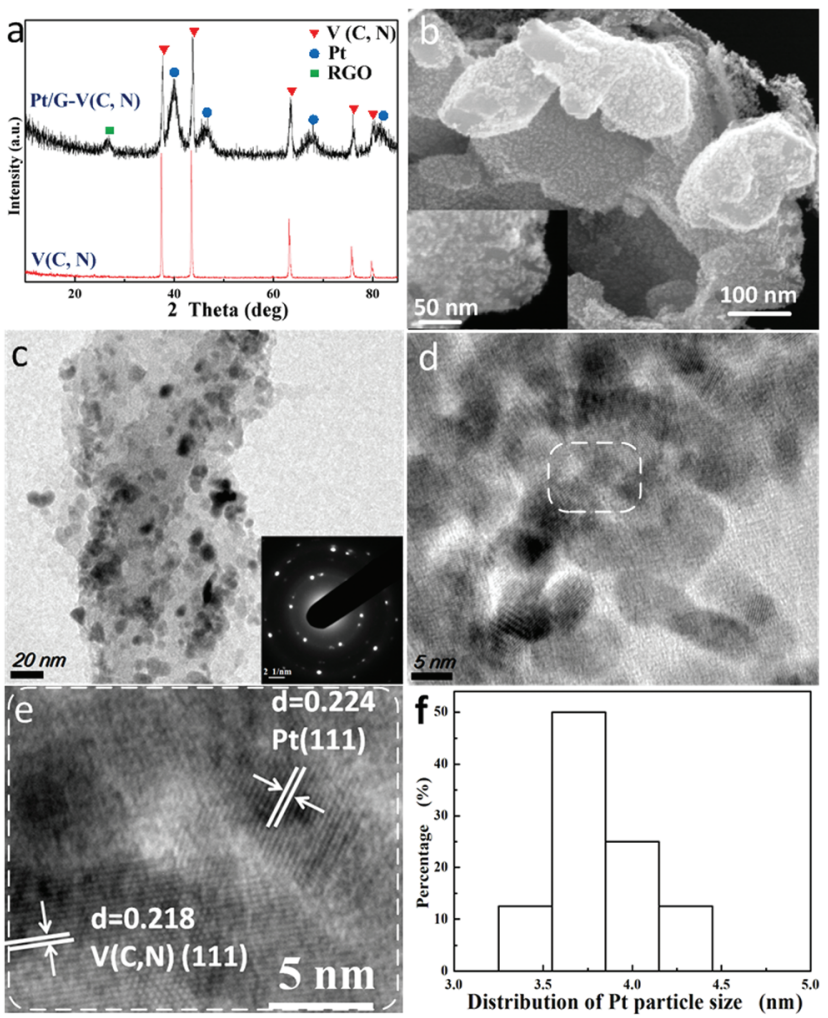

Fig. 1 (a) XRD patterns of $V(C, N)$ and $P t / G-V(C, N)$; (b) SEM image of $\mathrm{Pt} / \mathrm{G}-\mathrm{V}(\mathrm{C}, \mathrm{N})$; the magnified inset image shows that the Pt nanoparticles uniformly distributed on the $\mathrm{G}-\mathrm{V}(\mathrm{C}, \mathrm{N})$ support; (c) TEM image of Pt/ $\mathrm{G}-\mathrm{V}(\mathrm{C}, \mathrm{N})$; the inset is the corresponding SAED pattern; (d) and (e) HRTEM images of $\mathrm{Pt} / \mathrm{G}-\mathrm{V}(\mathrm{C}, \mathrm{N})$; (f) particle size distribution of $\mathrm{Pt}$ nanoparticles.

SEM images were recorded to study the morphology of the hybrid catalysts. Based on the SEM images (Fig. 1b), relatively large $\mathrm{V}(\mathrm{C}, \mathrm{N})$ nanoparticles were anchored on the graphene surface, while tiny Pt nanoparticles were evenly distributed on both $\mathrm{V}(\mathrm{C}, \mathrm{N})$ nanoparticles and the graphene surface.

The open structure of the hybrids with a large surface area is beneficial to the methanol oxidation reaction on the catalyst and methanol interface. Fig. 1c shows a TEM image of Pt/ $\mathrm{G}-\mathrm{V}(\mathrm{C}, \mathrm{N})$. It is clearly seen that $\mathrm{V}(\mathrm{C}, \mathrm{N})$ and Pt are uniformly distributed on the RGO surface. The inset in Fig. 1c shows the SAED patterns of $\mathrm{Pt} / \mathrm{G}-\mathrm{V}(\mathrm{C}, \mathrm{N})$, which can be indexed to the (111) facet of Pt and V(C, N) and are consistent with the XRD results. Similar growth directions were also observed in porous Pt structures and carbon nanotube-supported platinum. ${ }^{5,30}$ It is believed that Pt grows in a facile manner based on the close match in lattice constants between FCC V(C, N) and FCC Pt, leading to parallel growth directions. Fig. 1d and e show highresolution TEM (HRTEM) images of $\mathrm{Pt} / \mathrm{G}-\mathrm{V}(\mathrm{C}, \mathrm{N})$. The lattice spacings measured from $\mathrm{V}(\mathrm{C}, \mathrm{N})(0.218 \mathrm{~nm})$ and Pt nanoparticles $(0.224 \mathrm{~nm})$ match well with the (111) facets of $\mathrm{V}(\mathrm{C}, \mathrm{N})$ and Pt. Fig. 1f shows the size distributions of Pt nanoparticles on the catalyst support by measuring the particle size in SEM and TEM images. The results indicate that the average size of $\mathrm{Pt}$ nanoparticles is $3.7 \mathrm{~nm}$. To further investigate the morphology and composition of $\mathrm{Pt} / \mathrm{G}-\mathrm{V}(\mathrm{C}, \mathrm{N})$, SEM elemental mapping and EDS tests were performed. The elemental mapping and EDS data of Pt/G-V(C, N) show that Pt, V, N, and C elements coexist in the hybrids and the intensities of element signals match well with the Pt nanoparticles, $\mathrm{V}(\mathrm{C}, \mathrm{N})$, and graphene.

The surface chemistry of the hybrid catalysts was investigated by XPS spectroscopy and the results are shown in ESI $\dagger$ Fig. S2. Fig. S2a† is the survey XPS spectrum of $\mathrm{Pt} / \mathrm{G}-\mathrm{V}(\mathrm{C}, \mathrm{N})$, which suggests the presence of Pt, V, N, C, and $\mathrm{O}$ elements in the catalyst. This is consistent with the EDS results shown in Fig. 2. Fig. S2b $\dagger$ shows the high-resolution XPS spectrum of Pt $4 \mathrm{f}\left(4 \mathrm{f}_{7 / 2}\right.$ at $70.9 \mathrm{eV}$ and $4 \mathrm{f}_{5 / 2}$ at $\left.74.25 \mathrm{eV}\right)$. Fig. S2c $\dagger$ clearly shows that, in addition to $\mathrm{V} 2_{3 / 2}(517.95 \mathrm{eV})$ and $\mathrm{V} 2 \mathrm{p}_{1 / 2}$ (524.65 eV), vanadium forms chemical bonds with carbon $(\mathrm{V}-\mathrm{C}$ at $517.3 \mathrm{eV})$ and nitrogen $(\mathrm{V}-\mathrm{N}$ at $515.5 \mathrm{eV})$, respectively. ${ }^{31}$ This is consistent with the binary solid-solution phase diagrams of vanadium carbides and nitrides. ${ }^{32}$ The binding energy of nitrogen in nitrogen-vanadium $(\mathrm{N}-\mathrm{V})$ bonds is around $396.9 \mathrm{eV}$. Nitrogen also binds with carbon $(\mathrm{N}-\mathrm{C}$ at $397.5 \mathrm{eV}$ ) and oxygen (N-O at $398.5 \mathrm{eV}$ ); however, the intensity of the $\mathrm{N}-\mathrm{C}$ or $\mathrm{N}-\mathrm{O}$ bond is fairly weak compared with that of the $\mathrm{N}-\mathrm{V}$ bond. The binding energy of the $\mathrm{N}-\mathrm{V}$ bond is consistent with the theoretical calculation results. ${ }^{33}$ Fig. S2e $\dagger$ shows the XPS spectrum of C1s. The strongest peak located at $284.3 \mathrm{eV}$ is assigned to the $\mathrm{C}-\mathrm{C}$ bond that originates from the RGO. The intensity of the $\mathrm{C}-\mathrm{V}(283.1 \mathrm{eV})$ bond is smaller than that of the $\mathrm{C}-\mathrm{C}$ bond, which confirms the existence of the $\mathrm{V}(\mathrm{C}, \mathrm{N})$ phase. This is consistent with the XRD results. Fairly weak $\mathrm{C}-\mathrm{N}(285.7 \mathrm{eV}), \mathrm{C}-\mathrm{O}(285.2 \mathrm{eV})$ and $\mathrm{C}=\mathrm{O}(287.1 \mathrm{eV})$ bonds are also found in the catalyst sample. Fig. $\mathrm{S} 2 \mathrm{f} \dagger$ illustrates the state of oxygen. It is clearly seen that the $\mathrm{C}-\mathrm{O}$

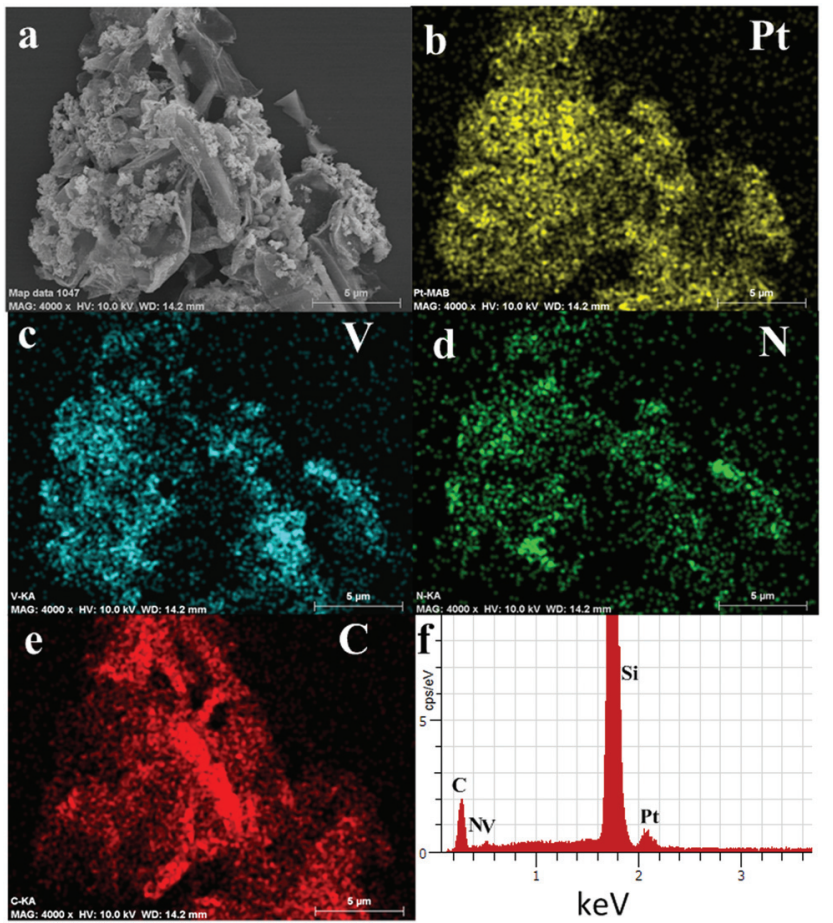

Fig. 2 SEM image, elemental mappings, and EDS data of Pt/G-V(C, N). 
(529.4 eV), $\mathrm{V}-\mathrm{O}(530.2 \mathrm{eV}), \mathrm{O} 1 \mathrm{~s}(531.6 \mathrm{eV})$, and $\mathrm{N}-\mathrm{O}(532.9 \mathrm{eV})$ bonds coexist in the sample. The O1s XPS spectrum shows that oxygen can eventually replace nitrogen in a metal nitride lattice. ${ }^{34}$ ESI $\dagger$ Fig. S3 shows the Raman spectra of $\mathrm{Pt} / \mathrm{G}-\mathrm{V}(\mathrm{C}$, $\mathrm{N})$. Typical bands of RGO were identified in the Raman spectra: D $\left(1340 \mathrm{~cm}^{-1}\right), \mathrm{G}\left(1573 \mathrm{~cm}^{-1}\right)$, and $2 \mathrm{D}\left(2700 \mathrm{~cm}^{-1}\right)$.

Fig. 3a shows the cyclic voltammograms (CVs) of Pt/ $\mathrm{G}-\mathrm{V}(\mathrm{C}, \mathrm{N})$ and commercial Pt/C tested in Ar-saturated $1.0 \mathrm{M}$ $\mathrm{KOH}$. The CV curves have quite a similar shape, which shows that $\mathrm{Pt} / \mathrm{G}-\mathrm{V}(\mathrm{C}, \mathrm{N})$ and $\mathrm{Pt} / \mathrm{C}$ have similar catalytic characteristics in Ar-saturated $\mathrm{KOH}$ solution. Fig. 3b shows the CV results of $\mathrm{Pt} / \mathrm{G}-\mathrm{V}(\mathrm{C}, \mathrm{N})$ and $\mathrm{Pt} / \mathrm{C}$ for catalyzing methanol oxidation in 1.0 M KOH with $0.5 \mathrm{M}$ methanol solution. The reaction current of the methanol oxidation peak from $\mathrm{Pt} / \mathrm{G}-\mathrm{V}(\mathrm{C}, \mathrm{N})$ is $48 \mathrm{~mA} \mathrm{~cm}^{-2}$, which is more than three times higher than that of the $\mathrm{Pt} / \mathrm{C}\left(15 \mathrm{~mA} \mathrm{~cm}^{-2}\right)$, indicating a greatly enhanced catalytic activity for methanol oxidation. In addition, it was also found that the onset potential of methanol oxidation with $\mathrm{Pt} /$ $\mathrm{G}-\mathrm{V}(\mathrm{C}, \mathrm{N})$ has a $50 \mathrm{mV}$ negative shift (from -0.52 to $-0.57 \mathrm{~V}$ ) compared with the $\mathrm{Pt} / \mathrm{C}$ catalyst, indicating a higher performance of $\mathrm{Pt} / \mathrm{G}-\mathrm{V}(\mathrm{C}, \mathrm{N})$ than that of $\mathrm{Pt} / \mathrm{C}$. The catalytic activity of
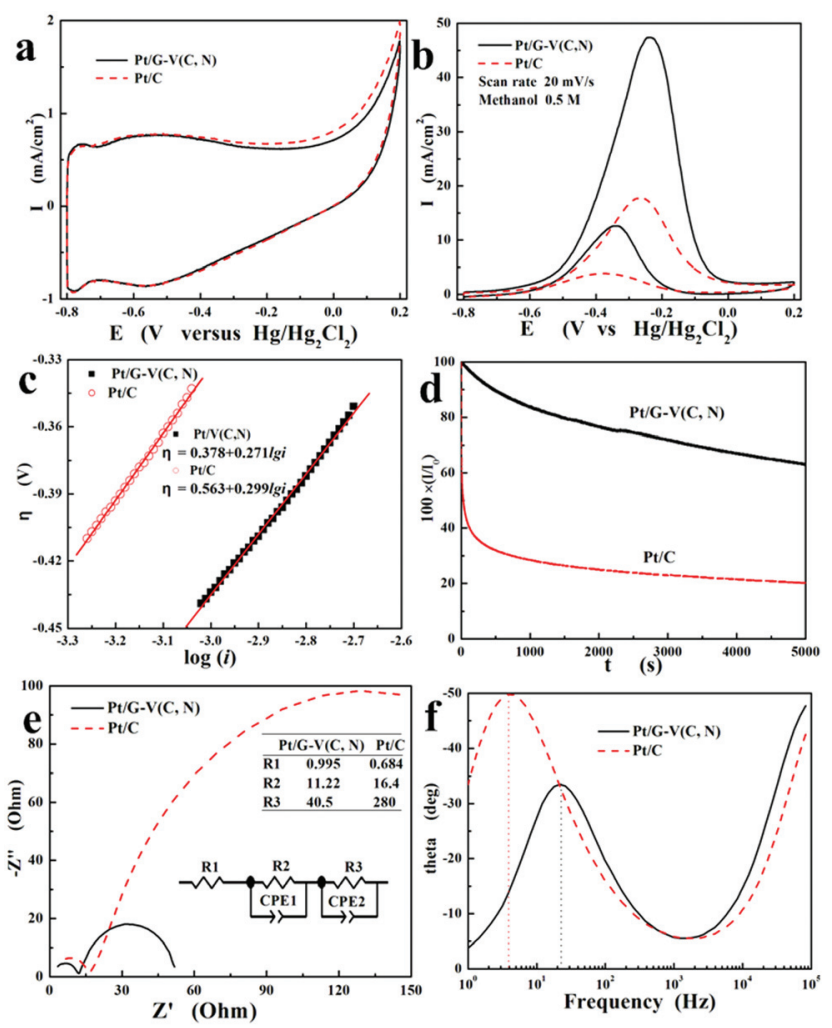

Fig. 3 (a) Cyclic voltammograms (CVs) of $\mathrm{Pt} / \mathrm{G}-\mathrm{V}(\mathrm{C}, \mathrm{N})$ and $\mathrm{Pt} / \mathrm{C}$ in an Ar-saturated $1.0 \mathrm{M} \mathrm{KOH}$ solution at a scan rate of $5 \mathrm{mV} \mathrm{s}^{-1}$; (b) CV curves of methanol oxidation with $\mathrm{Pt} / \mathrm{G}-\mathrm{V}(\mathrm{C}, \mathrm{N})$ and $\mathrm{Pt} / \mathrm{C}$ in $1.0 \mathrm{M} \mathrm{KOH}$ and $0.5 \mathrm{M}$ methanol; (c) Tafel plots of $\mathrm{Pt} / \mathrm{G}-\mathrm{V}(\mathrm{C}, \mathrm{N})$ and $\mathrm{Pt} / \mathrm{C}$ at a scan rate of $5 \mathrm{mV} \mathrm{s}^{-1}$; (d) current $(I)$-time $(t)$ chronoamperometric curves of Pt/ $\mathrm{G}-\mathrm{V}(\mathrm{C}, \mathrm{N})$ (black solid line) and $\mathrm{Pt} / \mathrm{C}$ (red dashed line) to methanol oxidation in $1.0 \mathrm{M} \mathrm{KOH}$ and $0.5 \mathrm{M}$ methanol (at $-0.24 \mathrm{~V}$ vs. $\mathrm{Hg} / \mathrm{Hg}_{2} \mathrm{Cl}_{2}$ ); (e) EIS results of $\mathrm{Pt} / \mathrm{G}-\mathrm{V}(\mathrm{C}, \mathrm{N})$ and $\mathrm{Pt} / \mathrm{C}$ at $-0.40 \mathrm{~V}$ vs. $\mathrm{Hg} / \mathrm{Hg}_{2} \mathrm{Cl}_{2}$. The insets are the equivalent circuit and the corresponding parameters; (f) Bode plots of $\mathrm{Pt} / \mathrm{G}-\mathrm{V}(\mathrm{C}, \mathrm{N})$ and $\mathrm{Pt} / \mathrm{C}$ for EIS data at $-0.40 \mathrm{~V}$ vs. $\mathrm{Hg} / \mathrm{Hg}_{2} \mathrm{Cl}_{2}$.
Pt towards methanol oxidation is promoted by the $\mathrm{G}-\mathrm{V}(\mathrm{C}, \mathrm{N})$ support. With a decrease of chemisorption energy, the methanol oxidation at the interface of $\mathrm{G}-\mathrm{V}(\mathrm{C}, \mathrm{N})$ and Pt nanoparticles is greatly enhanced due to the facilitated electrolyte/ reactant diffusion. ${ }^{35}$ The enhanced peak current and the shifted onset potential of methanol oxidation indicated that a higher energy density could be achieved in fuel cells for practical applications. Previous density-functional theory calculations suggested that the interaction between graphene and the metal clusters improves the stability of the interface. ${ }^{36}$ The chemisorption energies of $\mathrm{H}$ and $\mathrm{CO}$, the intermediate products of methanol oxidation, on the metal clusters supported by graphene become smaller than those on clusters without the graphene support.

Fig. 3c shows the Tafel plots of Pt/G-V(C, N) and Pt/C for catalyzing the methanol oxidation, which follows the following equation:

$$
\eta=a+b \lg i=-\frac{2.3 R T}{\alpha n F} \lg i_{0}+\frac{2.3 R T}{\alpha n F} \lg i
$$

where $i_{0}$ is the exchange current density, $\alpha$ is the charge transfer coefficient, $F$ is the Faraday constant, $R$ is the gas constant, and $T$ is the absolute temperature in $\mathrm{K}^{37}$ The calculated exchange current densities $i_{0}$ of $\mathrm{Pt} / \mathrm{G}-\mathrm{V}(\mathrm{C}, \mathrm{N})$ and $\mathrm{Pt} / \mathrm{C}$ catalyzing the methanol oxidation reaction are $0.038 \mathrm{~mA}$ and $0.013 \mathrm{~mA}$, respectively. The exchange current density of Pt/ $\mathrm{G}-\mathrm{V}(\mathrm{C}, \mathrm{N})$ is about three times higher than that of $\mathrm{Pt} / \mathrm{C}$. The charge transfer coefficients $\alpha$ of the methanol oxidation reaction with $\mathrm{Pt} / \mathrm{G}-\mathrm{V}(\mathrm{C}, \mathrm{N})$ and $\mathrm{Pt} / \mathrm{C}$ are 0.107 and 0.097 , respectively. The charge transfer coefficient of $\mathrm{Pt} / \mathrm{G}-\mathrm{V}(\mathrm{C}, \mathrm{N})$ catalyzing the methanol oxidation is also higher than that of $\mathrm{Pt} / \mathrm{C}$. This is consistent with the CV results, which also demonstrate that the $\mathrm{G}-\mathrm{V}(\mathrm{C}, \mathrm{N})$ support improves the catalytic performance of Pt.

The durability of $\mathrm{Pt} / \mathrm{G}-\mathrm{V}(\mathrm{C}, \mathrm{N})$ and $\mathrm{Pt} / \mathrm{C}$ catalysts during long-term operation was evaluated by chronoamperometric curves. Fig. 3d illustrates the current $(I)$-time $(t)$ chronoamperometric of $\mathrm{Pt} / \mathrm{G}-\mathrm{V}(\mathrm{C}, \mathrm{N})$ and $\mathrm{Pt} / \mathrm{C}$. It is shown that $\mathrm{Pt} /$ $\mathrm{G}-\mathrm{V}(\mathrm{C}, \mathrm{N})$ is more stable than the $\mathrm{Pt} / \mathrm{C}$ catalyst during longtime operation. The enhanced stability of $\mathrm{Pt} / \mathrm{G}-\mathrm{V}(\mathrm{C}, \mathrm{N})$ likely originates from the following superior features over the $\mathrm{Pt} / \mathrm{C}$ catalyst: a smaller support size, better dispersion of Pt nanoparticles, and strong binding between the support and $\mathrm{Pt}$ nanoparticles. $^{38}$

Fig. 3e and $\mathrm{f}$ show the electrochemical impendence spectroscopy (EIS) spectra of $\mathrm{Pt} / \mathrm{G}-\mathrm{V}(\mathrm{C}, \mathrm{N})$ and $\mathrm{Pt} / \mathrm{C}$ catalysts. The shape of EIS spectra is related to the mechanisms governing the fuel reaction. ${ }^{39}$ The two semicircles correspond with two reactions during the methanol oxidation. The high frequency semi-circle is related to the process of methanol oxidation to the intermediate product $\mathrm{Pt}(\mathrm{CHO})$, and the low frequency semi-circle is related to the final oxidation product $\mathrm{CO}_{2}$ and $\mathrm{H}_{2} \mathrm{O}:{ }^{40,41}$

$$
\begin{gathered}
\mathrm{Pt}\left(\mathrm{CH}_{3} \mathrm{OH}\right)+3 \mathrm{OH}^{-}=\mathrm{Pt}(\mathrm{CHO})+3 \mathrm{H}_{2} \mathrm{O}+3 \mathrm{e}^{-}, \\
\mathrm{Pt}(\mathrm{CHO})+3 \mathrm{OH}^{-}=\mathrm{Pt}+\mathrm{CO}_{2}+2 \mathrm{H}_{2} \mathrm{O}+3 \mathrm{e}^{-} .
\end{gathered}
$$


As illustrated in Fig. 3e, both $\mathrm{Pt} / \mathrm{G}-\mathrm{V}(\mathrm{V}, \mathrm{N})$ and $\mathrm{Pt} / \mathrm{C}$ show low series resistances. The first semicircle at high-frequency $(R 2)$ illustrates the initial oxidation of methanol. The semicircle radius of $\mathrm{Pt} / \mathrm{G}-\mathrm{V}(\mathrm{C}, \mathrm{N})$ catalyzing methanol oxidation is smaller than that of $\mathrm{Pt} / \mathrm{C}$, which implies that the reaction resistance of $\mathrm{Pt} / \mathrm{G}-\mathrm{V}(\mathrm{C}, \mathrm{N})$ catalyzing the methanol oxidation is lower than that of $\mathrm{Pt} / \mathrm{C}$. This implies that the initial step of methanol oxidation is easier to occur for $\mathrm{Pt} / \mathrm{G}-\mathrm{V}(\mathrm{C}, \mathrm{N})$, which can be attributed to additional active sites on the surfaces of RGO and $\mathrm{V}(\mathrm{C}, \mathrm{N})$ nanoparticles generated by carbon and nitrogen anion-induced defects. Fig. 3e also shows that $R 3$, which usually represents the main oxidation resistance, of $\mathrm{Pt} / \mathrm{G}-\mathrm{V}(\mathrm{C}, \mathrm{N})$ is lower than that of $\mathrm{Pt} / \mathrm{C}$. The decreased resistance is attributed to the significant synergistic effect towards methanol oxidation in $\mathrm{G}-\mathrm{V}(\mathrm{C}, \mathrm{N})$ that induces a faster oxidation process. Fig. $3 \mathrm{f}$ shows the Bode plots of methanol oxidation under the catalysis of $\mathrm{Pt} / \mathrm{G}-\mathrm{V}(\mathrm{C}, \mathrm{N})$ and $\mathrm{Pt} / \mathrm{C}$. It is clearly shown that the corresponding peak frequency of methanol oxidation under the catalysis of $\mathrm{Pt} / \mathrm{G}-\mathrm{V}(\mathrm{C}, \mathrm{N})$ is higher than that of $\mathrm{Pt} / \mathrm{C}$, which indicates a shorter electron lifetime, suggesting a faster electron transfer from the Pt catalyst to methanol. The result also indicates that the catalytic activity of Pt is enhanced by $\mathrm{G}-\mathrm{V}(\mathrm{C}, \mathrm{N})$.

$\mathrm{CV}$ curves of methanol oxidation with different methanol concentrations are shown in Fig. $4 \mathrm{a}$ and b. Both catalysts show similar catalytic characteristics towards methanol oxidation with an increase in catalytic current with increasing methanol concentration. Fig. 4c clearly reveals that, for both $\mathrm{Pt} / \mathrm{G}-\mathrm{V}(\mathrm{C}, \mathrm{N})$ and $\mathrm{Pt} / \mathrm{C}$, the onset potential of methanol oxidation decreases with increasing methanol concentration due to the enhanced methanol diffusion. The increased methanol concentration accelerates the diffusion of methanol to the interface of catalysts and eventually promotes the reaction. Therefore, the methanol oxidation onset potentials have negative shifts with increasing methanol concentration. The shift of the onset potential is also related to the presence of oxygen-containing functional groups on the graphene nanosheet. ${ }^{42}$ The oxygen-containing functional groups could promote the diffusion of methanol oxide intermediates. Based on the results shown in Fig. 4c, the negative shift in methanol oxidation onset potential of $\mathrm{Pt} / \mathrm{G}-\mathrm{V}(\mathrm{C}, \mathrm{N})$ compared with $\mathrm{Pt} / \mathrm{C}$ is further confirmed.

Fig. 4d summarizes the peak current densities of methanol oxidation of both catalysts with increasing methanol concentration. The current density of $\mathrm{Pt} / \mathrm{G}-\mathrm{V}(\mathrm{C}, \mathrm{N})$ increases more significantly than that of $\mathrm{Pt} / \mathrm{C}$. Initially, the current density of $\mathrm{Pt} /$ $\mathrm{G}-\mathrm{V}(\mathrm{C}, \mathrm{N})$ is slightly higher than that of $\mathrm{Pt} / \mathrm{C}$ with $0.1 \mathrm{M}$ methanol and increases to three times higher at a concentration of $0.5 \mathrm{M}$, and finally reaches five times higher at a concentration of $2.0 \mathrm{M}$. The lower onset potential and the higher current density suggest that $\mathrm{Pt} / \mathrm{G}-\mathrm{V}(\mathrm{C}, \mathrm{N})$ possesses higher catalytic activity than the $\mathrm{Pt} / \mathrm{C}$ catalyst. ${ }^{43}$ The enhanced catalytic activity is attributed to the decreased activation energy of methanol oxidation. ${ }^{22}$ Based on the dependence of $I$ on the methanol concentration $(c)$, the reaction order can be deduced according to the slope between $I$ and $c:^{44,45}$

$$
\text { Rate } \equiv I=k c^{n},
$$
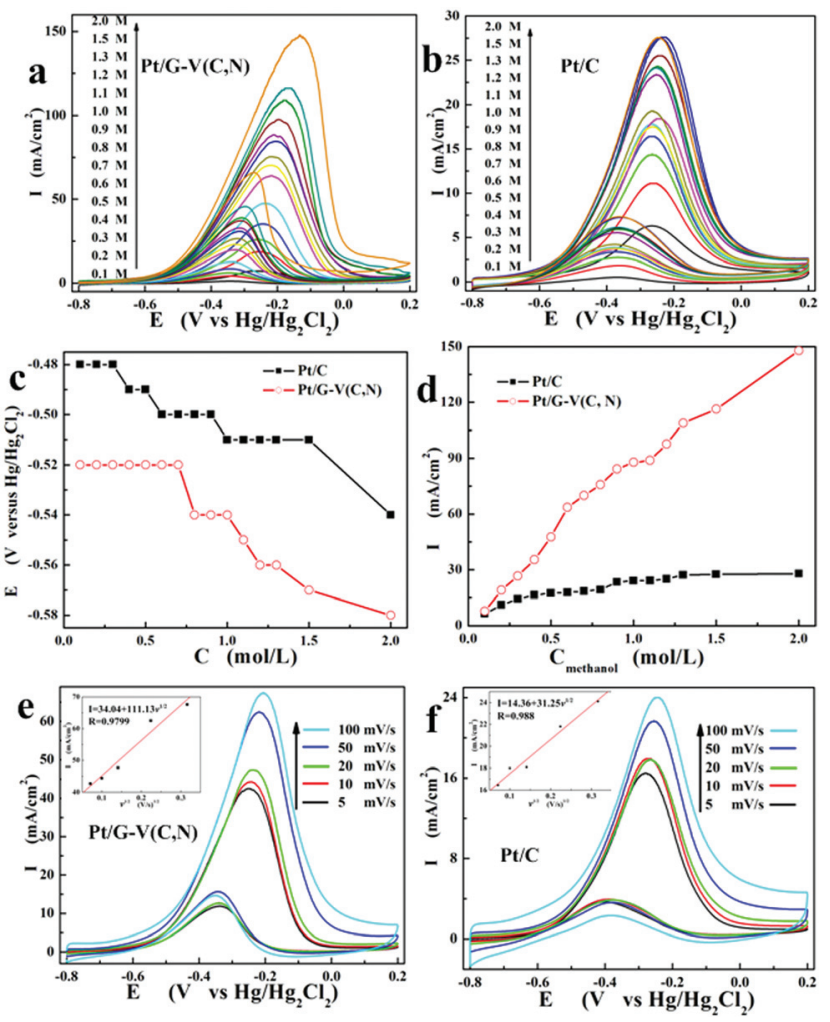

Fig. $4 \mathrm{CV}$ curves of methanol oxidation at a scan rate of $50 \mathrm{mV} \mathrm{s}^{-1}$ with (a) $\mathrm{Pt} / \mathrm{G}-\mathrm{V}(\mathrm{C}, \mathrm{N})$ and (b) $\mathrm{Pt} / \mathrm{C}$ in $1.0 \mathrm{M} \mathrm{KOH}$ solution with different methanol concentrations; (c) the correlation of the methanol oxidation onset potential with methanol concentration; (d) the correlation of the methanol oxidation peak current with methanol concentration; CV curves of methanol oxidation with (e) $\mathrm{Pt} / \mathrm{G}-\mathrm{V}(\mathrm{C}, \mathrm{N}$ ) and (f) $\mathrm{Pt} / \mathrm{C}$ at different scan rates in $1.0 \mathrm{M} \mathrm{KOH}$ and $0.5 \mathrm{M}$ methanol. The inset illustrates the dependence of the methanol oxidation peak current on the square root of the scan rate.

$$
\log (I)=\log (k)+n \log (c)
$$

where $I$ is the peak current density, $k$ is the reaction rate constant, $c$ is the bulk concentration of methanol, and $n$ is the reaction order. The reaction rate constant values of $\mathrm{Pt} / \mathrm{G}-\mathrm{V}(\mathrm{C}$, $\mathrm{N})$ and Pt/C catalysts are 73.5 and 11.2, respectively.

Fig. $4 \mathrm{e}$ and $\mathrm{f}$ show the CVs in $1.0 \mathrm{M} \mathrm{KOH}$ and $0.5 \mathrm{M}$ methanol with different scan rates. It is found that, for both Pt/ $\mathrm{G}-\mathrm{V}(\mathrm{C}, \mathrm{N})$ and $\mathrm{Pt} / \mathrm{C}$, the peak current density increases with an increase of the $\mathrm{CV}$ scan rate. The insets in Fig. 4e and f illustrate the dependence of peak current on the square root of the scan rate $\left(v^{1 / 2}\right)$. The quasi-linear dependence of the anode peak current on $v^{1 / 2}$ suggests that the methanol oxidation is a diffusion-controlled process. ${ }^{46}$ The diffusion of methanol and methanol oxide intermediates on the surface of $\mathrm{Pt} / \mathrm{G}-\mathrm{V}(\mathrm{C}, \mathrm{N})$ is much faster than that on the $\mathrm{Pt} / \mathrm{C}$ surface, which is also confirmed by the Tafel results. The methanol oxidation usually proceeds by a multiple-site mechanism. ${ }^{19}$ The adsorption of methanol oxides on the Pt surface by an oxygenated species adsorbed on the adjacent Pt site is a rate-determining step. The surface state of the catalyst influences the convection of methanol and the related methanol oxidation intermediate. ${ }^{47}$ 
The convection of the methanol oxide intermediate is accelerated on the surface of RGO-supported $\mathrm{V}(\mathrm{C}, \mathrm{N})$. So the oxidation of methanol could be fully executed, which results in a significantly enhanced methanol oxidation peak current. Previously reported $\mathrm{W}_{2} \mathrm{C}$-supported Pt also bears a similar mechanism for enhanced catalytic performance towards methanol oxidation. ${ }^{19}$ Moreover, the coexisting carbon and nitrogen anioninduced surface defects also improve the methanol oxidation on the interface between $\mathrm{V}(\mathrm{C}, \mathrm{N})$ and $\mathrm{Pt}^{25}$ To further confirm the improved catalytic performance of the Pt catalyst with the $\mathrm{G}-\mathrm{V}(\mathrm{C}, \mathrm{N})$ support, a graphene supported Pt catalyst was also prepared and tested in methanol oxidation. The methanol oxidation characteristics with Pt/graphene at different methanol concentrations and with different scan rates are shown in ESI $\dagger$ Fig. S4. The results clearly show that the forward current intensities of methanol oxidation with the Pt/graphene catalyst are smaller than those of $\mathrm{Pt} / \mathrm{G}-\mathrm{V}(\mathrm{C}, \mathrm{N})$ with the same methanol concentrations or under the same scan rates. These results further confirm the advantages of the $\mathrm{G}-\mathrm{V}(\mathrm{C}, \mathrm{N})$ support over the pure graphene support for Pt catalysts in a methanol oxidation reaction.

\section{Conclusions}

A graphene-vanadium carbonitride $(\mathrm{G}-\mathrm{V}(\mathrm{C}, \mathrm{N}))$ hybrid was synthesized in situ through the reduction of GO-supported $\mathrm{V}_{2} \mathrm{O}_{3}$ under an ammonia atmosphere and used as a highly efficient support for the Pt catalyst. The as-synthesized Pt/ $\mathrm{G}-\mathrm{V}(\mathrm{C}, \mathrm{N})$ catalyst shows an improved electrocatalytic performance and better stability during long-term operation for methanol electro-oxidation compared with the commercial Pt/ C catalyst. More importantly, the new $\mathrm{Pt} / \mathrm{G}-\mathrm{V}(\mathrm{C}, \mathrm{N})$ catalyst is suitable for higher energy density applications. The catalytic performance of $\mathrm{Pt}$ towards methanol oxidation is greatly promoted by the $\mathrm{G}-\mathrm{V}(\mathrm{C}, \mathrm{N})$ support. The novel $\mathrm{G}-\mathrm{V}(\mathrm{C}, \mathrm{N})$ hybrid nanostructure may inspire the design of new high-performance electrocatalysts that are attractive for a wide range of applications in heterogeneous catalysis, gas storage, energy conversion, and energy storage.

\section{Acknowledgements}

Financial support for this work was provided by the U.S. Department of Energy (DE-EE0003208), the Research Growth Initiative Program of the University of Wisconsin-Milwaukee (UWM), Promotive Research Fund for Young and Middle-aged Scientists of Shandong Province, China (No. BS 2011CL005), and Science Development Project of Shandong Province China (No. J11LD02 and No. 2014GGX104004). The authors thank Professor M. Gajdardziska-Josifovska for TEM access at the UWM HRTEM Laboratory, Dr. H. A. Owen for technical support with SEM analyses, Dr. S. E. Hardcastle for technical support with XRD and XPS analyses, and Mr. Jianyang Li for help with the structure diagram. The SEM imaging was conducted at the UWM Electron Microscope Laboratory. The XRD and XPS were conducted at the UWM Advanced Analysis Facility.

\section{Notes and references}

1 J. Luo, P. N. Njoki, Y. Lin, D. Mott, L. Y. Wang and C.-J. Zhong, Langmuir, 2006, 22, 2892-2898.

2 J. H. Zeng, J. Yang, J. Y. Lee and W. J. Zhou, J. Phys. Chem. $B, 2006,110,24606-24611$.

3 I. Avila-Garcia, C. Ramirez, J. M. H. Lopez and E. M. A. Estrada, J. Alloys Compd., 2010, 495, 462-465.

4 Y. Shao, G. Yin, Z. Wang and Y. Gao, J. Power Sources, 2007, 167, 235-242.

5 S. M. Alia, G. Zhang, D. Kisailus, D. S. Li, S. Gu, K. Jensen and Y. S. Yan, Adv. Funct. Mater., 2010, 20, 3742-3746.

6 V. Bambagioni, C. Bianchini, A. Marchionni, J. Filippi, F. Vizza, J. Teddy, P. Serp and M. Zhiani, J. Power Sources, 2009, 190, 241-251.

7 G. Che, B. B. Lakshmi, E. R. Fisher and C. R. Martin, Nature, 1998, 393, 346-349.

8 K. I. B. Eguiluz, G. R. P. Malpass, M. M. S. Pupo, G. R. Salazar-Banda and L. A. Avaca, Energy Fuels, 2010, 24, 4012-4024.

9 G. Girishkumar, K. Vinodgopal and P. V. Kamat, J. Phys. Chem. B, 2004, 108, 19960-19966.

10 L. Li and Y. C. Xing, Energies, 2009, 2, 789-804.

11 Y. Li, W. Gao, L. Ci, C. Wang and P. M. Ajayan, Carbon, 2010, 48, 1124-1130.

12 L. W. Liao, S. X. Liu, Q. Tao, B. Geng, P. Zhang, C. M. Wang, Y. X. Chen and S. Ye, J. Electroanal. Chem., 2011, 650, 233-240.

13 C. W. Xu, Z. Q. Tian, P. K. Shen and S. P. Jiang, Electrochim. Acta, 2008, 53, 2610-2618.

14 R. G. Freitas, L. R. Marchesi, R. T. S. Oliveira, F. I. MattosCosta, E. C. Pereira, L. O. S. Bulhoes and M. C. Santos, J. Power Sources, 2007, 171, 373-380.

15 J. W. Guo, T. S. Zhao, J. Prabhuram, R. Chen and C. W. Wong, J. Power Sources, 2006, 156, 345-354.

16 O. T. M. Musthafa and S. Sampath, Chem. Commun., 2008, 67-69.

17 K. Kakinuma, Y. Wakasugi, M. Uchida, T. Kamino, H. Uchida and M. Watanabe, Electrochemistry, 2011, 79, 399-403.

18 M. M. O. Thotiyl, T. Ravikumar and S. Sampath, J. Mater. Chem., 2010, 20, 10643-10651.

19 R. Ganesan and J. S. Lee, Angew. Chem., Int. Ed., 2005, 44, 6557-6560.

20 K. G. Nishanth, P. Sridhar, S. Pitchumani and A. K. Shukla, Fuel Cells, 2012, 12, 146-152.

21 D. Ham and J. Lee, Energies, 2009, 2, 873-899.

22 J. L. Cohen, D. J. Volpe and H. D. Abruna, Phys. Chem. Chem. Phys., 2007, 9, 49-77.

23 D. Chen, H. Feng and J. Li, Chem. Rev., 2012, 112, 6027-6053.

24 M. Liu, R. Zhang and W. Chen, Chem. Rev., 2014, 114, 5117-5160. 
25 J. S. Spendelow, Q. Xu, J. D. Goodpaster, P. J. A. Kenis and A. Wieckowski, J. Electrochem. Soc., 2007, 154, F238-F242.

26 E. Herrero, Q. S. Chen, J. Hernandez, S. G. Sun and J. M. Feliu, Phys. Chem. Chem. Phys., 2011, 13, 1676216771.

27 D. R. Rolison, Science, 2003, 299, 1698-1701.

28 T. Huang, S. Mao, H. Pu, Z. Wen, X. Huang, S. Ci and J. Chen, J. Mater. Chem. A, 2013, 1, 13404-13410.

29 T. Huang, S. Mao, G. Zhou, Z. Wen, X. Huang, S. Ci and J. Chen, Nanoscale, 2014, 6, 9608-9613.

30 H. Chu, Y. Shen, L. Lin, X. Qin, G. Feng, Z. Lin, J. Wang, H. Liu and Y. Li, Adv. Funct. Mater., 2010, 20, 3747-3752.

31 E. F. de Souza, C. A. Chagas, T. C. Ramalho and R. B. de Alencastro, Dalton Trans., 2012, 41, 14381-14390.

32 P. Duwez and F. Odell, J. Electrochem. Soc., 1950, 97, 299304.

33 R. Sanjines, C. Wiemer, P. Hones and F. Levy, J. Appl. Phys., 1998, 83, 1396-1402.

34 I. P. Parkin and G. S. Elwin, J. Mater. Chem., 2001, 11, 3120-3124.

35 Y.-S. Wang, S.-Y. Yang, S.-M. Li, H.-W. Tien, S.-T. Hsiao, W.-H. Liao, C.-H. Liu, K.-H. Chang, C.-C. M. Ma and C.-C. Hu, Electrochim. Acta, 2013, 87, 261-269.
36 Y. Okamoto, Chem. Phys. Lett., 2006, 420, 382-386.

37 S. Lee, H. J. Kim, S. M. Choi, M. H. Seo and W. B. Kim, Appl. Catal., A, 2012, 429-430, 39-47.

38 B. Wu, D. Hu, Y. Kuang, B. Liu, X. Zhang and J. Chen, Angew. Chem., Int. Ed., 2009, 48, 4751-4754.

39 E. P. Murray, T. Tsai and S. A. Barnett, Nature, 1999, 400, 649-651.

40 O. A. Khazova, A. A. Mikhailova, A. M. Skundin, E. K. Tuseeva, A. Havranek and K. Wippermann, Fuel Cells, 2003, 2, 99-108.

41 A. V. Miller, V. V. Kaichev, I. P. Prosvirin and V. I. Bukhtiyarov, J. Phys. Chem. C, 2013, 117, 8189-8197.

42 E. Yoo, T. Okata, T. Akita, M. Kohyama, J. Nakamura and I. Honma, Nano Lett., 2009, 9, 2255-2259.

43 W. Li, Y. Bai, F. Li, C. Liu, K.-Y. Chan, X. Feng and X. Lu, J. Mater. Chem., 2012, 22, 4025-4031.

44 B. Beden, F. Kadirgan, C. Lamy and J. M. Leger, J. Electroanal. Chem., 1982, 135, 171.

45 E. Telli, R. Solmaz and G. Kardas, Russ. J. Electrochem., 2011, 47, 811-818.

46 R. M. A. Tehrani and S. Ab Ghani, Fuel Cells, 2009, 9, 579587.

47 S. L. Gojković, J. Electroanal. Chem., 2004, 573, 271-276. 